\title{
Bireysel Yatırımeı Demografileri: Osmaniye İlinde Risk Getiri Tercihlerinin Multinominal Probit Modeliyle İncelenmesi
}

\author{
Mehmet CIHANGIR* \\ Nazan ŞAK** \\ Şeyma BÍLGIN***
}

\section{ÖZET}

Bireysel yatırımcılar, kendi nam ve hesaplarına işlem yapan bireylerdir. Çalışmada bireysel yatırımcıların risk getiri tercihlerini etkileyen faktörler, çeşitli demografik özelliklerden yararlanılarak incelenmeye çalışılmıştır. Araştırma, Osmaniye ilindeki bireysel yatırımcılar baz alınarak, tesadüfi örnekleme yöntemi ile farklı meslek gruplarından rassal olarak seçilen bireylere anket tekniği kullanılarak yapılmıştır. Elde edilen veriler "Multinominal Probit Modeli" kullanılarak değerlendirilmiş neticede bireysel yatırımcıların bazı demografik özelliklerde risk alma düzeylerinin farklılıklar gösterdiği gözlenmiştir. Model tahmini sonucunda demografik faktörlerden cinsiyet ve medeni durum değişkenlerinin bireylerin risk tercihlerinde etkili olduğu bulgusuna ulaşılmıştır.

Anahtar Kelimeler: Bireysel Yatırımcl, Risk, Risk Algisı, Demografik Özellikler, Multinominal Probit Model, Osmaniye

JEL Sinıflandırması: C25, D81, G02, G11

Individual Investor Demographics: Investigation Of Risk Return Preferences in Osmaniye with Multinomial Probit Model

\section{ABSTRACT}

Individual investors are individuals who make transaction for self accounts. In the study, the factors that influenced individual investors risk return preferences has been investigated by means of various demographic features. Investigation has been carried out by using survey method with random sampling and based upon individual investors who selected randomly from different occupational groups in Osmaniye province. The obtained data has been examined by using "Multinomial Probit Model". Eventually, it has been observed that individual investors risk taking levels show differences in some demographic features. As a result of model estimate, it has been attained demographic factors gender and marital status variables are effective on individuals risk preferences.

Key Words: Individual Investor, Risk, Risk Perception, Demographic Features, Multinomial Probit Model, Osmaniye

JEL Classification: C25, D81, G02, G11

\footnotetext{
* Doç. Dr. Mehmet Cihangir, Osmaniye Korkut Ata Üniversitesi, İktisadi ve İdari Bilimler Fakültesi, İşletme Bölümü, Muhasebe Finansman Anabilim dalı, Osmaniye, Türkiye: cihangir@osmaniye.edu.tr

** Yrd. Doç. Dr. Nazan Şak, Osmaniye Korkut Ata Üniversitesi,İktisadi ve İdari Bilimler Fakültesi, Ekonometri Bölümü, Osmaniye, Türkiye: nazansak@osmaniye.edu.tr

*** Şeyma Bilgin, Sorumlu Yazar, Osmaniye Korkut Ata Üniversitesi, Sosyal Bilimler Enstitüsü, İşletme Anabilim dalı, Yüksek Lisans Öğrencisi: bilginseymaa@gmail.com
} 


\section{GíRİş}

Bireysel yatırımcılar, genel olarak kendi nam ve hesaplarına küçük çapta işlem yapan yatırımcılardır. Bireysel yatırımcıların risk algılamaları ve getiriye yönelik tercihleri profesyonelce değildir. Onların kararlarında psikolojik ve demografik özelliklerin de etkisi önemlidir. Genel anlamda bir tehlikenin gerçekleşme olasılı̆̆ ile gerçekleşmesi halinde oluşabilecek sonucun şiddetinin birlikte ele alınması risk olarak adlandırılırken finans literatüründe işlem sonunda gerçekleşen getirinin beklenen getiriden sapma olasıllğına risk adı verilmektedir.

Bireysel yatırımcı riski farklı şekillerde algılamaktadır. Riski para kaybetmek ya da rahatsız edici bir şey yapmak olarak tanımlayan yatırımcı, riski para kaybettikten sonra fark etmektedir. Bununla birlikte bireysel yatırımcılarda, bilinmeyenden korkma eğilimi vardır ve birçoğu daha önce zarar ettiği bir senede ya da bir araca yatırım yapmaktan korkmaktadır (Karan, 2013: 732).

Günümüzde eğitim seviyesi, yaş aralığı ve gelir düzeyi ne olursa olsun milyonlarca kadın ve erkek çok çeşitli sebeplerle finansal piyasalarda işlem yapmaktadır. Finans sektörünün her türlü yatırımcının ihtiyacına uygun menkul kıymetler sunabilme becerisi gün geçtikçe artarken, bu durum aynı etkiyi yatırımcı profilindeki çeşitliliğin hızlı bir şekilde artması üzerinde de göstermektedir. Finansal piyasaların ölçeği üzerinde etkili olan yatırımcı profilindeki bu değişim, piyasaların değerlendirilmesinde özellikle göz önünde bulundurulması gereken bir faktör olarak ortaya çıkmaktadır (Saraç ve Kahyaoğlu, 2011: 136).

Geleneksel finans araştırmaları, yatırımcıyı pek çok veriyi elde ettikten sonra bunları sayısal analize tabi tutup elde edecekleri faydayı maksimize etmeyi hedefleyen ve bu hedefe ulaşmada rasyonaliteyi ölçüt alan, benmerkezci varlıklar olarak kabul eder. Ayrıca bu geleneksel modeller piyasanın etkin olduğunu savunurlar. Zamanla bu modeller piyasaların etkinliğini ve bireylerin rasyonelliğini açıklamada yetersiz kalmaya başlamışlardır. Özellikle geleneksel finansın piyasada oluşan ve anomali olarak da isimlendirilen bazı düzensizlikleri açıklamadaki yetersizliği "Davranışsal Finans" adında yeni bir bilim dalının doğmasına neden olmuştur (Gümüş vd., 2013: 73).

$\mathrm{Bu}$ çalışmanın amacı, yatırımcıların üstlendikleri riskin belirleyicisi olarak algılanan risk seviyesinin ve bunların sonuçlarının demografik özellikler yardımıyla ortaya konulmasıdır. Bu kapsamda çalışmada çeşitli demografik özelliklere sahip gruplar arasında risk alma eğilimine göre farklılıkların olup olmadığı analiz edilmektedir.

Araştırmanın bundan sonraki bölümünde öncelikle davranışsal finans ve bireysel yatırımcı demografileri etkisiyle risk getiri tercihleri konuları işlenip literatür taramasına değinilecek, takiben bireysel yatırımcı demografilerinin yaşlara göre risk alma düzeylerini ölçmede kullanılan veri toplama yönteminden bahsedilecektir. Daha sonra analizde kullanılan 
yöntem hakkında bilgi verilerek veriler yardımıyla elde edilen analiz ve bulgular açıklanacak son bölümde ise multinominal probit model sonuçları yorumlanacaktır.

\section{DAVRANIŞSAL FINANS VE BİREYSEL YATIRIMCI TERCIHLERİ}

"Standart finansta insanlar rasyoneldir. Davranışsal finansta ise normal." (Statman, 2014: 73'ten aktaran Özerol, 2011: 9). Daha geniş bir ifadeyle; klasik finans bilimi, insanı rasyonel bir varlık olarak kabul eder. Hatta buna paralel olarak iktisat bilimi de, en iyiyi en ucuza mal etme çabasını göz önünde bulundurarak insanın rasyonalitesini belirtir. Ancak, son yıllarda pek çok bilim adamı insanoğlunun verdiği kararlarda rasyonel olmadığı yönünde tespitlerde bulunmuştur. Bu sebeple, davranışsal finans yardımıyla piyasalardaki işlemlere ilişkin alınan kararlarda neden akılcı ya da akıl dışı davranıldığı açıklanmaya başlanmıştır.

Klasik finans sisteminde bireylerin nasıl davranması gerektiğini ifade eden yaklaşıma karşılık; davranışsal finans, bireylerin hangi sebeplerle bu şekilde davrandıklarını kendisine araştırma konusu edinmiştir (Aren vd., 2014: 41). Davranışsal finans, bireyin yatırım kararı verirken üst düzey karmaşık analizlerde bulunmak yerine, psikolojik ve sosyolojik etmenlerin yönlendirmesiyle hareket ettiğini iddia eden, onların finans piyasası üzerindeki görüş ve kararlarını yine onların davranışları ile açıklayan bir olgudur. Yatırımcı kimi zaman hırsının ya da cesaretinin, kimi zaman inancının ya da çevresinin, kimi zaman da sosyal statüsünün etkisi altında kalarak finansal işlemleri için karar verir (Gümüş vd., 2013: 73).

Finansman yazınında bazı önyargıların nedenini araştıran davranışsal finans yaklaşımında; yatırımcıların her koşulda portföylerini maksimize etmek isteyecekleri ve daima kendi çıkarlarını gözeteceklerine yönelik bir varsayım bulunmaktadır (Fuller, 2000: 34'ten aktaran Taner ve Akkaya, 2005: 48).

Finans piyasalarının şekillenmesine sebep olan yatırımcı kararları, geleneksel finansın varsayımlarını destekleyecek biçimde olmayıp, çoğunlukla mantıksal temellere dayanmazken, yatırımcıların psikolojik yönlerinden ve önyargılarından fazlasıyla etkilenmektedir. Bilhassa, finansal kararları etkileyen en önemli faktör olan bireysel risk algısı, kişilerin ruh hallerindeki anlık değişmelerle sürekli farklılık gösterdiği için rasyonel birey kavramının sorgulanmasının gerekli olduğu düşüncesini haklı çıkarmaktadır (Sefil ve Çilingiroğlu, 2011: 249).

Geleneksel finans teorilerinin açıklayamadığı anomalilerin ve karar alma süreci bileşenlerinin kaynağı olarak insan psikolojisini işaret eden davranışsal finans, özellikle sosyoloji ve psikoloji gibi davranış bilimlerinin yardımıyla fayda teorisi ve dar tanımlı rasyonel davranış kavramlarının keşfedilmesi ve açıklanmasıyla ilgilenmektedir (Sefil ve Çilingiroğlu, 2011: 252-253). Dolayısıyla davranışsal finans modelleri finansal piyasalarda işlem yapan insanların nasıl hareket etmesi gerektiğini değil, gerçekte nasıl hareket ettiklerini belirlemeyi amaç edinmiştir (Bostancı, 2003: 10). Bu anlamda yatırımcının sahip olduğu demografik özelliklerin aldığı kararlar üzerindeki etkisi davranışsal finansın bir inceleme konusu olarak karşımıza çıkmaktadır. 
Bireysel yatırımcılar yatırım kararı alırken kişisel, finansal ve çevresel olmak üzere üç ana etkenin etkisi altında kalırlar. Bu etkenlerden birincisi olan kişisel faktörler; yatırımcıların yeterli bilgi ve zamanlarının olması, yaşı, cinsiyeti, sağlık durumu, gelir düzeyi, yaşam biçimi, beklentileri ve psikolojik durumlarıdır. İkinci etken olan finansal faktörler; yatırımcıların ellerindeki mevcut sermayeyi koruma, sermayede değer artışı sağlama ve sürekli gelir elde etme isteğinden oluşur. Üçüncü etken olan çevresel faktörler ise; yatırımcıların içinde bulunduğu sosyal ve kültürel durum, referans grubu, grup ve aile ilişkisini kapsamaktadır (Özaltın vd., 2015: 402-404).

Yatırımc1lar yatırım kararı vermeden önce, yatırımdan beklediği getiriyi ve söz konusu yatırımın taşıdığı riskleri bilmelidir. Zira yatırımının ne derece risk taşıdığını ölçebilen yatırımcılar daha başarılı kararlar alabilecektir (Sarıkamış, 2000: 163). Buna bağlı olarak finansal risk algılamasını etkileyen faktörler; kişilik özellikleri (dışa dönüklülük-içe dönüklülük, uyumluluk, sorumluluk-amaçsızlık, duygusal denge, yeniliklere açık olma) ile psikolojik faktörler (hevristikler, bilişsel önyargılar, duygusal faktörler) ve demografik ve sosyo-ekonomik faktörler (cinsiyet, yaş, medeni durum, eğitim düzeyi, meslek, ailedeki birey sayısı, aylık gelir, mal varlığı, finansal bilgi düzeyi) olmak üzere iki ana gruba ayrılırlar. Bu faktörlerdeki herhangi bir değişim yatırımcının finansal risk algısını değiştirecektir. Bu yüzden yatırımcıların risk algısının statik değil dinamik olduğu ileri sürülebilir (Saraç ve Kahyaoğlu, 2011: 138).

\section{LITERATÜR TARAMASI}

Yatırımciların finansal risk algılamaları ile demografik ve ekonomik durumları arasındaki ilişki boyutlarının tartışıldığı bir çalışma Anbar ve Eker tarafından yapılmıştır. Çalışmada, demografik ve sosyoekonomik değişkenler ile bireyin finansal risk toleransı arasında yakın bir ilişki olduğu varsayılmış ve bu değişkenlere göre yatırımcıların risk profilleri çıkarılmaya çalışılmıştır. Genel olarak, kişilerin biyolojik yapılarının, kişilik özelliklerinin, demografik ve sosyoekonomik değişkenlerinin finansal risk toleransını etkilediğini gözler önüne seren çalışmada varsayımlanan görüşleri destekleyecek sonuçların elde edilmesiyle birlikte, bu görüşlerin aksini gösteren sonuçlarında elde edildiği gözlenmiştir (Anbar ve Eker, 2009).

Kahyaoğlu tarafından İstanbul Menkul Kıymetler Borsası'nda 1 Ocak 2007 ile 31 Aralık 2009 tarihleri arasında, 31 bireysel yatıımcının gerçekleştirdiği hisse senedi alımsatım işlemlerine ilişkin gerçek veriler kullanılarak yapılan çalışmada, çeşitli psikolojik ve duygusal faktörlere maruz kalma seviyeleri açısından kadın ve erkek yatırımcılar arasında istatistiksel olarak anlamlı farklılıklar olduğu belirlenmiştir. Çalışmada kadın yatırımcıların risk algısının erkek yatırımcılardan yüksek olduğu sonucuna varılmıştır (Kahyaoğlu, 2011).

Usul vd. tarafindan yapılan çalışmada, bireysel yatırımcıların meslek, yaş, öğrenim ve gelir durumları gibi özelliklerinin; hisse senetlerine yapacakları yatırımların oranını, yatırım süresini, risk alma düzeylerini ve risk alma oranlarını etkilediği gözlenmiştir. Bu farklılıkların 
bireysel yatırımcıların ayrı bir kültür, bilgi ve psikolojik yapı ile eğitim düzeylerinin farklı olmasından kaynaklandığını öngören bu çalı̧̧a, sosyoekonomik etkenlerin yatırımcının kendi kişisel yapısından kaynaklandığı kadar, çevresel yapılardan da kaynaklandığı kanısını paylaşmış hisse senedi ediniminde, her bireysel yatırımcı farklı türden davranışlar sergilediklerini teyit etmişlerdir (Usul vd., 2002).

Gümüş vd., Türkiye ve Azerbaycan'daki yatırımcıların yatırım kararlarını alırken bazı önyargı, duygu, sezgi ve yanlış düşünce kalıplarının etkisi altında hareket edip etmediklerini anlamak amacıyla bir anket hazırlanıp her iki ülkede 384 kişiye uygulamışlardır. Sonuçlara göre yatırımcıların kararları üzerinde gelir ve eğitim seviyesinin, medeni durumun, yaş ve cinsiyetin farklılaşmaya neden olduğu tespit edilmiştir. Uygulama sonucunda, davranışsal finans modellerinin Türk ve Azeri yatırımcılarının finansal kararlarını açıklama düzeyi test edilerek, çoğunlukla demografik faktörlerin ve zenginleştiremedikleri bazı psikolojik faktörlerin davranışçı modelleri destekler şekilde bu yatırımcıların aldığı kararlarda etkili olduğu sonucu ortaya çıkmıştır (Gümüş vd., 2013).

Saraç ve Kahyaoğlu tarafindan İMKB'de 2007-2009 yılları arasında hisse senedi yatırımı yapan bireysel yatırımcıların, üstlendikleri risk düzeyleri ile ilişkili olan sosyoekonomik ve demografik faktörler incelenmiştir. Bu kapsamda çeşitli özelliklere sahip gruplar arasında risk alma eğilimine göre farklılıkların olup olmadığına bakılmış, nihayetinde yatırımcının yaşı, cinsiyeti, medeni durumu, mesleği, çocuk sayısı, eğitim durumu ve gelir düzeyinin yatırımcıların üstlenmek istediği risk seviyesini belirleyen en önemli faktörler olduğu kanısına varılmıştır (Saraç ve Kahyaoğlu, 2011).

Lutfi tarafından Endonezya'nın Surabaya kentinde 84 yatıımcı örneği kullanılarak yapılan çalışmada yatırımcıların demografik faktörleri (cinsiyet, yaş, medeni durum, eğitim, gelir ve aile nüfusu) ve risk davranışları (riski seven, riskten kaçınan) arasında ilişki kurulmuş, bu ilişkinin yatırım türleri (banka ürünleri, sermaye piyasası araçları ve fiziksel varlıklar) ile ilişkilendirildiği gözlemlenmiştir. Çalışma, demografik faktörlerin yatırımcıların risk toleransını ve tercih haklarını açıklamakla birlikte, risk toleransı ile yatırım tercihleri arasında anlamlı bir ilişkinin olduğunu da ortaya koymuştur (Lutfi, 2009).

Nguyen ve Schübler tarafından yapılan bir diğer çalışmada, yatırımcıların finansal kararlarının psikolojik faktörlerden etkilendiği, bu nedenle tipik hatalar yapıldığı varsayılarak bu hataları test etmek için Alman yatırımcılarla bir anket çalışması yapılmıştır. Ayrıca deneyim, eğitim ve geliri etkileyen davranışların sosyo-demografik özelliklere dayanıp dayanmadığı analiz edilmeye çalışılmıştır. Çalışma; sistematik hataların Alman yatırımcılar arasında yaygın olduğunu ve eğitimin yatııımcı davranışını tahmin etmekte en iyi test özelliği olduğu sonuçlarına ulaşmıştır (Nguyen ve Schübler, 2012).

Rajdev'in1992 yılında anket yardımıyla yaptığı çalışma, Kalpataru Multiplier Ltd. Şti. bünyesinde çalışan Bhopal'lı 100 yatırımcı üzerinde gerçekleştirilmiştir. Hindistan'da yapılan bu araştırma, farklı demografik faktörler içeren yatırımcıların kararlarını etkileyecek farklı 
yatırım kararları üzerinde durmuştur. Yatırımcıların demografik faktörlerine odaklanan çalışmada psikolojik yönler görmezden gelinerek ihmal edilmiş, yatırımcının yatırım kararı ve risk davranışııın da onların psikolojik durumunu etkileyebileceği sonucuna ulaşılmıştır (Rajdev, 2013).

Florida Eyalet Kurulu idaresi tarafindan 2008 yılında detaylı demografik bilgileri birleştiren veri seti kullanılarak Florida'nın okul bölgelerinde eğitim durumu anketi yapılmıştır. Bununla katılımcıların risk tercihlerini belirlemek amaçlanmıştır. Regresyon analizinden faydalanılarak yapılan bu çalışma kadınların ve siyahların, sırayla erkekler ve beyazlara göre daha muhafazakâr bir tutum sergilediğini göstermektedir. Bu uygulama cinsiyet ve ırk faktörünün yatırım tercihlerinde rol oynadığını kanıtlamakla birlikte diğer ölçülebilir faktörlerin bunlara belirgin bir şekilde bağlanabileceğini kanıtlamıştır (Farrell, 2011).

Zaidi ve Tauni tarafından yapılan bir araştırmada yatırımcıların kişisel özellikleri, demografileri ve Lahor Borsası Aşırı Güven Endeksi (LSE) arasındaki ilişki incelenmiştir. Farklı istatistiksel araçlar kullanılan araştırmanın sonucunda bulgular, aşırı güven önyargısı ve uyumluluk, dışadönüklük ve bilinç arasında pozitif; aşırı güven önyargısı ve nevroz arasında negatif bir ilişki olduğunu göstermiştir. Aynı zamanda yatırım deneyimi ile aşırı güven önyargısı arasında bir ilişki olduğu da ortaya çıkmıştır. Araştırma Lahor Borsası Aşırı Güven Endeksi (LSE)'nin mevcut veriler kullanıldığında tamamen rasyonel olmadığı sonucunu ortaya koymuştur (Zaidi ve Tauni, 2012).

Özerol vd., hisse senedi portföyündeki belli demografik değişkenlerin (yaş, cinsiyet, eğitim ve medeni durum) ve ticaret stratejilerinin (portföy değeri, ciro oranı, yatırım dönemi, danışmanlık tavsiye, uyumlu ve uyumsuz) etkilerinin araştırılması amacıyla bir çalışma yapılmışı̧ı. Araştırma 60 bireysel yatıımoının 1996-2001 aras1 6 yıllık ticaret faaliyetlerinden oluşan veri setinin analizi ile yatırımcıların gerçek portföyleri incelenerek gerçekleştirilmiştir. Bulgular, portföy değeri ve ciro oranlarının genel yatırımcılara az miktarda önerildiğini, böylece pazarın üstün bir performans sergileme eğiliminde olduğunu göstermiştir. Araştırmanın korelasyon tablosu incelendiğinde erkeklerin yüksek güvenleri nedeniyle ticarette kadınlardan daha fazla göründükleri sonucuna ulaşılmıştır (Özerol vd., 2011).

Jain ve Mandot tarafından yapılan bir çalışmada, risk düzeyi ve yatırımcıların demografik faktörleri arasındaki ilişkiyi araştırılmıştır. Araştırma medeni durum, cinsiyet, yaş ile risk düzeyi arasında negatif, yatırımcıların eğitim, meslek, yaşadığı şehir, gelir düzeyi ve yatırımcıların bilgileri ile risk düzeyi arasında pozitif bir korelasyon olduğunu ortaya koymuştur (Jain ve Mandot, 2012).

Sadiq ve Ishaq tarafından yapılan çalışmada demografik faktörlerin yatırımcılar üzerinde etkisini incelemek, yatırım seçiminde risk toleransını saptamak amaçlanmıştır. İncelemeler, Pakistan'daki Rawalpindi ve İslamabad şehirlerinde 100 gerçek yatırımcı seçilerek, ki-kare testi ve korelasyon analizi uygulanarak yapılmıştır. Araştırma, akademik 
yeterlilik, gelir düzeyi, yatırım bilgisi ve yatırım deneyiminin yatırımcı davranışları üzerinde önemli bir etkiye sahip olduğunu göstermiştir. Bu demografiler arasında pozitif korelasyon görülmekle beraber, sadece yatırımcının yaşı negatif korelasyon eğilimi göstermektedir. Bir noktadan sonra yaş artmasının risk alma davranışı üzerinde olumsuz bir etkiye neden olduğu kanısına ulaşılmıştır (Sadiq ve Ishaq, 2014).

Literatürde bireysel yatırımcı demografileri etkisiyle risk getiri tercihlerinin incelendiği çalışmalarda çoklu tercih modellerine yer verilmediği görülmektedir. Burada ise, söz konusu risk getiri tercihleri Multinominal Probit modeli kullanılarak elde edilmeye çalışılmış ve çalı̧̧ma bu yönüyle bir ilk olarak benzer nitelikteki araştırmalardan farklılık göstermiştir.

\section{ARAŞTIRMADA KULLANILAN VERILIER}

Araştırma kapsamında bireysel yatırımcı demografileri etkisiyle yatırımcıların risk getiri tercihleri, çeşitli demografik özelliklere sahip gruplar arasında incelenmeye çalışılmıştır. Çalışma, Osmaniye ilinde ikamet eden 150 bireysel yatırımcı üzerinde bireysel yatırımcı demografileri baz alınarak risk getiri tercihlerinin bulunması amacıyla, yüz yüze anket yöntemi kullanılarak gerçekleştirilmiştir.

Kullanılan yüz yüze anket yöntemi formu Ede (2007), Elmas (2010) ve Özcan (2011) makalelerinin ölçeklerinden yararlanılarak oluşturulmuştur.

Tesadüfi örnekleme metodu ile farklı meslek gruplarından rassal olarak 15'er kişi seçilerek yüz yüze anket yöntemi kullanılmıştır. Bu iş kolları imalat sanayi, gıda, sağlık, eğitim, bankacılık ve finans, adalet, küçük ölçekli esnaf, inşaat ve emlak, elektrik-elektronik, mobilya, turizm, kuyumculuk ve mücevherat, muhasebe ve mali işler, basın yayın ve eğlence sektöründen oluşmaktadır.

Çalışmada demografik değişkenler; cinsiyet, yaş, medeni durum, eğitim, gelir durumları olarak belirlenmiştir. Bu değişkenlere bağlı olarak bireysel yatırımcıların risk alma düzeyleri ve risk alma oranları ile ilgili veriler elde edilerek, kullanılan değişken ve veriler arasındaki ilişkinin nasıl olduğu tespit edilmeye çalışılmıştır. Elde edilen veriler, istatistik paket programları kullanılarak analiz edilmiştir.

\section{YÖNTEM}

Analizde çoklu tercih modellerinden çok durumlu (multinominal) probit model kullanılmıştır. Multinominal probit modeli, rassal fayda teorisine dayanan nitel tercih modelidir ve faydanın maksimizasyonuna dayanır. Modelde, $m$ seçim durumundan $j$. seçimin faydası aşağıdaki gibi ifade edildiğinde,

$$
U_{j}=V_{j}+\varepsilon_{j}, \quad j=1, \ldots, m
$$

biçiminde belirtilen fayda fonksiyonunda yer alan hata terimi, normal dağılıma sahip olacaktır (Cameron ve Trivedi, 2006: 516). Multinominal Probit modelinde dağılımın korelasyon yapısı üzerine bir kısıtlama yoktur. Modelin en önemli avantajı, seçenekler 
arasında ilişki olabilmesine izin vermesidir, yani IIA varsayımına bakılması şart değildir (Cameron ve Trivedi, 2009: 503).

Multinomial probit modelin seçim olasıllığı,

$$
\begin{gathered}
P_{n}(i)=P\left(\varepsilon_{j, n}-\varepsilon_{i, n}<V_{i, n}-V_{j, n}, \forall j \neq i\right) \\
=\int_{\varepsilon_{n}} I\left(\varepsilon_{j, n}-\varepsilon_{i, n}<V_{i, n}-V_{j, n}, \forall j \neq i\right) \phi\left(\varepsilon_{n}\right) d \varepsilon_{n}
\end{gathered}
$$

olarak hesaplanır. Formüldeki $I$, fonksiyonu ifade ederken; $\phi\left(\varepsilon_{n}\right)$ ise, aşağıdaki şekilde elde edilir:

$$
\phi\left(\varepsilon_{n}\right)=\frac{1}{(2 \pi)^{\frac{1}{2}}\left|\Sigma_{n}\right|^{\frac{1}{2}}} e^{-\frac{1}{2} \varepsilon_{n}^{\prime} \Sigma_{n}^{-1} \varepsilon_{n}}
$$

Multinominal probit modelinin seçim olasılıkları hesaplanırken $I$ boyutlu integral alma işlemi yapılmalıdır. Bu integral alma işleminde de integral alma süreci yerine simülasyonlarla yaklaştırma işlemi uygulanır. $\mathrm{Bu}$ sebeple, multinominal probit modeli, maksimum simülasyonlarla elde edilmiş en çok benzerlik tahmincisi kullanılarak bulunur. Katsayı yorumu, marjinal etkilerin hesaplanmasıyla yapılmaktadır (Cameron ve Trivedi, 2006: 518).

\section{ANALIZZ VE BULGULAR}

$\mathrm{Bu}$ çalışmanın amacı, bireysel yatırımcıların yatırım kararları üzerinde etkili olan demografik faktörlerin tespit edilmesiyle, bunlara bağlı olarak gelişen risk getiri tercihlerinin belirlenmesidir. Risk getiri tercihlerini etkileyen faktörleri bulabilmek için çoklu tercih modellerinden multinominal probit modeli kullanılmışır.

Multinominal probit model tahminine geçmeden önce çalı̧̧madan elde edilen verilerden yararlanılarak örneklemin istatistiksel özellikleri incelenmiş, bu amaçla, çalışmanın güvenilirliği ve tutarlılığı belirlenerek, frekans dağılımları hakkında bilgi verilmiştir. Araştırmanın güvenilirliğini analiz etmek için anketteki likert ölçekli sorular incelenmiş, Cronbach Alpha katsayısı hesaplanmıştır. Bu değerin 0,70'in üzerinde olması çalışmanın güvenirliğinin yüksek olduğunu göstermektedir. Çalışmamızda anketteki sorular incelendiğinde Cronbach Alpha değerinin 0,82 olduğu bulunmuştur. Bu değer, analiz sonuçlarının güvenilir olduğunu göstermektedir. Çalışmanın ileriki dönemlerde kullanılabilirliğini incelemek için tutarlılık analizi yapılmış ve sonuçlar aşağıda verilmiştir. Tutarlılık analizinde anketteki sorular iki kısma ayrılmakta ve split half katsayısı hesaplanmaktadır. Çalışmamızda bu değerler, 0,73 ve 0,68 olarak bulunmuştur.

Araştırma bulgularının frekanslarının yüzde dağılımlarına bakıldığında, çalışmaya katılan bireylerin \%28'i kadın, \%72'si erkeklerden oluştuğu görülecektir. Konuyla ilgili diğer örnek makale çalışmalarında da görülen "erkek yatırımcıların kadınlara göre daha ağırlıkta 
olduğu" olgusu çalışmamızda da görülmüş ve teyit edilmiştir. Nitekim sonuçlar, Döm (2003), Ede (2007), Doğukanlı ve Önal (2000)'in çalışmalarını destekler niteliktedir.

Yaş değişkeninin frekans tablosunu incelediğimizde 26-30 yaş aralığındaki yatırımcıların risk alma eğilimlerinin \%36,7 ile en yükssek, 51-60 yaş aralığındaki yatırımcıların ise \%1,3 ile en düşük olduğunu görmekteyiz.

Şekil 1: Yaşın Yüzdelik Dağılımı

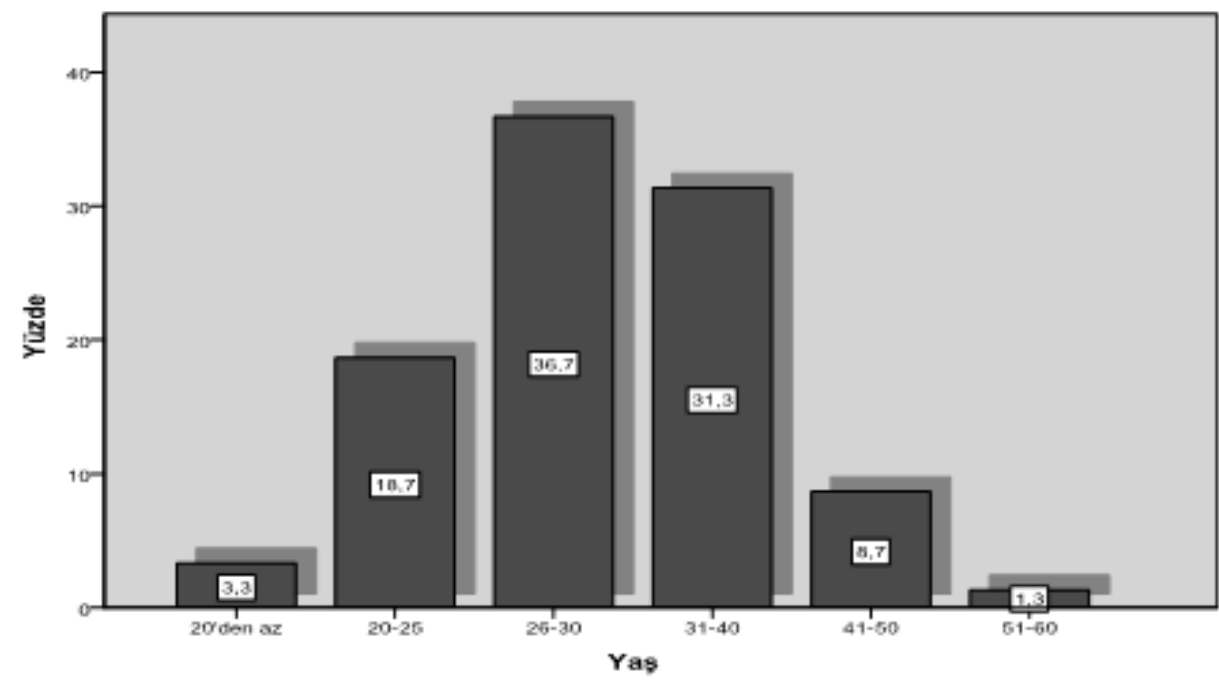

Yatırımcıların eğitim durumlarına göre dağılımına bakıldığında, \%0,7'sinin okur/yazar olduğu fakat herhangi bir diplomaya sahip olmadığı, \%3,3’ünün ilköğretim mezunu, \%24'ünün lise mezunu, \%61,3'ünün lisans mezunu yatırımcılar ve \%10,7'sinin de lisansüstü eğitim almış yatırımcılar olduğu belirlenmiştir. Yatırımcıların medeni durumlarına göre dağılımına bakıldığında ise, \%55,3'ünün evli \%44,7'sinin bekâr olduğu görülmüştür.

Son olarak yatırımcıların, aylık gelir durumlarına göre dağılımlarını incelediğimizde, \%40'lık en büyük kısmını 1000-2000TL arası aylık geliri olan yatırımcıların oluşturduğu gözlemlenmektedir. Ayrıca \%26,7'lik kısmını 2001-3000TL, \%19,3'lük kısmının 30014000TL, \%8,7'lik kısmın1 4001-5000TL ve \%4,7'lik k1smını ise 5001-10000TL aras1 aylik geliri olan yatırımcıların oluşturduğu görülmektedir. Aylık 10001TL ve üzerinde gelir elde eden yatırımcıların oran 1 ise $\% 0,7$ 'dir.

Çalışmada bireysel yatırımcıların ankette yer alan riskle ilgili sorulara verdikleri cevapların yüzde dağılımlarına bakıldığında, \%31,3'ünün riske girmeyi sevdiği, \%50'sinin kesin olarak riske girmeyi sevmediği, \%18,7'sinin ise riske girme eğilimlerinin bazen değiştiği görülmektedir. Bir benzeri olarak sorulan "Kaybetmekten korkar mısınız?" sorusuna yönelik yüzde dağılıma bakıldığında yatırımcıların \%59'unun kaybetmekten korktuğu, \%41'inin ise kaybetmeden korkmadığı sonucuna ulaşılmaktadır. Benzer nitelikteki bu iki sorunun oranlarının yakın olması anketin doğru değerlendirildiğini destekler niteliktedir. 
"Riski para kaybetmek ya da olumsuz bir durumla karşılaşmak olarak mı değerlendirirsiniz?" sorusunun yüzde dağılımına bakıldığında yatırımcıların \%54'ünün riski para kaybı ya da olumsuz bir durum olarak gördüğü, \%46'sının ise riski para kaybı ya da olumsuz bir durum olarak görmediği tespit edilmiştir. Yatırımcıların kazanç ve kayıplarına göre bakış açılarının yansıtıldığı "Yatııımcı kazandıktan sonra yüksek risk, kaybettikten sonra düşük risk alma eğilimindedir." düşüncesinin yüzde dağılımını ise, \%55'lik kısmını katılanlar, \%17'lik kısmını katılmayanlar oluşturmaktadır. Geriye kalan \%28'lik oranı ise, kararsızların oluşturduğu görülmektedir.

"Belirli bir kaybın verdiği üzüntü aynı miktarda kazancın vereceği memnuniyetten daha büyüktür." düşüncesine verilen cevaplarda yatırımcıların \%48'inin katıldığı, \%26'sının katılmadığı ve geriye kalan \%26'ının kararsız olduğu görülmektedir. Bu yüzdelik sonuçlar, bireysel yatırımcıların kaybı, aynı oranda kazançtan daha çok dikkate aldığını göstermektedir.

Uygulamada "Yatırımcılar geçmiş fiyat hareketlerini kullanarak gelecekle ilgili karar verirler." düşüncesine bireysel yatırımcıların \%15'inin katılmadığı, \%24'ünün ise kararsız kaldığı belirlenmiştir. \%60'ık oranın ise, bu soruya katılarak, bireysel yatırımcıların geçmişteki fiyat hareketlerden etkilenip yeni kararlar alabilecekleri izlenimini doğurmuştur.

"Aşağıdaki kişilik özelliklerinden hangisi size en yakın olanıdır?" sorusuna verilen cevapların \%48'inin "Güvenli", \%34,7'sinin "Dikkatli" seçeneklerinde yoğunlaştı̆ı gözlenirken; \%6'lık kısmının "Endişeli" ve \%11,3'lük kısmının ise "Duygusal" cevabını vermesi kişilik özelliklerinin yatırım kararlarına etkisini gözler önüne sermektedir.

Çalışmada "Kredili olarak hisse senedi alımı yapar mısınız?" sorusuna verilen cevaplar çok farklı yüzde dağılımlarıyla dikkat çekmiştir. Bireysel yatırımcıların \%10'u bu soruyu "Evet" olarak cevaplarken, \%90'ı "Hayır" cevabını vermiştir."Hisse senedi piyasasını yakından takip ediyor musunuz?" sorusuna verilen \%19,3'lük "Evet" ve \%80,7'lik "Hayır" cevabı, bireysel yatırımcıların hisse senedi alımına sıcak bakmadığını göstermektedir. Bireysel yatırımcılar, "Yatırım tercihlerinizi kendi ülkenize ait yatırım araçlarından yana mı kullanırsınız?" sorusuna \%84 oranında "Evet" derken, \%16 oranında "Hayır" diyerek tercihlerinin hangi yönde olduğunu belirtmişlerdir. Ayrıca "Portföyünüzde bulunan yatırım araçlarını tercih ederken göz önünde bulundurduğunuz temel faktör nedir?" sorusuna verilen dört birbirine yakın oranlı cevapların yanı sıra, \%36'lık oranla "Helal haram olgusu" cevabı ön plana çıkarak farklılık göstermiştir. Bu da Osmaniye ili bireysel yatırımcılarının dini eğilimlerinin yatırım tercihlerine etki ettiğini göstermektedir.

\section{UYGULAMA}

Modelde kullanılan bağımlı değişken, Osmaniye ilinde yaşayan bireysel yatırımcıların riske bakış açılarına göre oluşturulmuştur. Yatırımcıların her zaman riskli yatııımlara yönelme durumu 1, bazen riskli yatırımlara yönelme durumu 2, hiç riskli yatırıma yönelmemesi ise 3 değerini almaktadır. Bireylerin risk alma olasılıklarını etkileyen faktörler incelendiğinde, birçok seçenek arasında cinsiyet ve medeni durum değişkeninin istatistiksel 
olarak anlamlı bulunduğu gözlenmiştir. Aşağıda tahmin edilen multinominal probit modeli sonucu görülmektedir:

Tablo 1: Multinominal Probit Modeli Uygulama Sonuçları

\begin{tabular}{|c|c|c|c|c|c|c|c|}
\hline & likelihood ( & garitmik olas & ): -146.8897 & & $\begin{array}{r}\text { Gözlem Sa } \\
\text { Wald } \chi^{2} \\
\text { Prob. }\end{array}$ & $\begin{array}{lr}: & 150 \\
: & 12.2 \\
: & 0.0156\end{array}$ & \\
\hline & eğişkenler & Katsayılar & Std. Hata & Z Değeri & Prob. $>|\mathrm{z}|$ & 95\% Güv & Aralıkları \\
\hline & Cinsiyet & 0.7201765 & 0.3700711 & 1.95 & $0.052 *$ & -0.005149 & 1.445502 \\
\hline 1 & $\begin{array}{l}\text { Medeni } \\
\text { durum }\end{array}$ & -0.5867025 & 0.3167036 & -1.85 & $0.064^{*}$ & -1.207430 & 0.0340251 \\
\hline & Sabit terim & -0.6281319 & 0.3344852 & -1.88 & $0.060^{*}$ & -1.283711 & 0.0274471 \\
\hline 2 & & & & emel Grup & & & \\
\hline & Cinsiyet & -0.319950 & 0.3691069 & -0.87 & 0.386 & -1.04338 & 0.403486 \\
\hline 3 & $\begin{array}{c}\text { Medeni } \\
\text { durum }\end{array}$ & 0.454649 & 0.3563628 & 1.28 & 0.202 & -0.24380 & 1.153108 \\
\hline & Sabit terim & -0.841743 & 0.3476270 & -2.42 & 0.015 & -1.52308 & -0.160407 \\
\hline
\end{tabular}

*Test istatistiği \%10 düzeyinde anlamlıdır.

$\mathrm{Y}=2$ (Bazen risk alma durumu) Temel grup

Tahmin edilen multinominal probit modelinde temel grup olarak, bağımlı değişkenin 2 değerini aldığı "bazen riskli yatırımlara yönelme" durumu belirlenmiştir. Katsayı yorumu tahmin edilen modelden yapılamamakta, bu model vasıtasıyla sadece değişkenlerin işaretleri belirlenebilmektedir. Modelden elde edilen katsayıları yorumlayabilmek için marjinal etkiler elde edilmelidir. Aşağıdaki tabloda modelden elde edilen marjinal etkiler verilmiştir:

Tablo 2: Modelin Marjinal Etki Değer Sonuçları

\begin{tabular}{|l|l|c|c|c|c|}
\hline \multicolumn{7}{|c|}{ Marjinal Etkiler } \\
\hline & Değişkenler & Katsayılar & Standart Hata & Z Test İst. & Prob. \\
\hline Y=1 & Cinsiyet & 0.2024 & 0.07511 & $2.69^{*}$ & 0.007 \\
(Her zaman) & Medeni durum & -0.1940 & 0.07779 & $-2.49^{*}$ & 0.013 \\
\hline Y=3 & Cinsiyet & -0.1279 & 0.07962 & -1.61 & 0.108 \\
(Hiç) & Medeni durum & 0.1368 & 0.06206 & $2.21^{*}$ & 0.027 \\
\hline
\end{tabular}

*Test istatistiği \%10 düzeyinde anlamlıdır.

$\mathrm{Y}=2$ (Bazen risk alma durumu) karşılaştırma grubu

Model sonuçları incelendiğinde risk alma durumunu "her zaman" olarak belirtenlerde cinsiyet ve medeni durum değişkeni \%10 düzeyinde anlamlı bulunmuştur. Elde edilen katsayılar direkt yorumlanamayacağından marjinal etkiler tahmin edilmiş ve bu etkiler yorumlanmıştır. Multinominal probit modelden elde edilen marjinal etkiler incelendiğinde, diğer değişkenler sabitken "bazen" riskli yatırımlara yönelme temel sınıfına göre, "her zaman" riskli yatırımlara yönelmede erkekler, kadınlara göre \%0,2024 oranında daha fazla risk alma eğilimindedir. Her zaman risk alma durumu bazen risk alma durumuna göre 
değerlendirildiğinde ise evli bireylerin bekârlara göre \%0,1940 oranında daha az risk alma eğiliminde olduğu görülmektedir. Üçüncü kategori ( $\mathrm{Y=3}$ hiç risk almama durumu) incelendiğinde, evli olan bireyler "bazen" risk alma temel sınıfina göre,bekâr bireylerden $\% 0,1368$ oranında daha fazla risk almama eğilimindedir. Cinsiyet değişkeni incelendiğinde ise, erkeklerde "hiç" risk almama eğilimi kadınlara göre "bazen" risk alma temel sınıfıyla karşılaştırıldığında \%0,1279 oranında daha azdır.

\section{SONUÇ}

Bireylerin yatırım kararlarını alabilmesi ve başarılı bir şekilde uygulayabilmesi için, bireyin riske bakış açısının veya risk alma kapasitesinin bilinmesi önemlidir. Bireylerin, genel olarak riski sevmedikleri varsayımına karşın, her bireyin risk alma derecesi yani almak istediği belirsizlik tutarı değişmektedir. Bireylerin risk karşısındaki tutumlarını etkileyen birçok faktör bulunmaktadır. Yapılan çalışmalar, bireysel yatırımcıların risk alma eğilimlerinde demografik özelliklerin etkili olduğunu göstermektedir. Diğer bir ifadeyle, yatırımcının yaşı, cinsiyeti, medeni durumu, eğitimi ve aylık gelir düzeyi yatırımcının alabileceği risk seviyesini belirleyen önemli unsurlardır.

Finansal piyasaların risk ve getirisi ile ilgili yorumlanmasında demografik çeşitliliklerin göz önünde bulundurulması gerekmektedir. Araştırmada bireylerin demografik özelliklerinin risk getiri tercihleri üzerindeki etkilerini incelemek üzere, Osmaniye ilinde yaşayan bireysel yatırımcılara anket yöntemi uygulanmış, elde edilen veriler yardımıyla katılımcıların risk alma profilleri belirlenmeye çalışılış̧ıtır. Demografik özelliklerin risk alma tercihleri üzerine etkisi, mutinominal probit modeli kullanılarak incelenmiştir.

Çalışmadan elde edilen bulgular incelendiğinde, demografik özelliklerin bireylerin risk alma tercihlerinde etkili olduğu bulunmuştur. Bu sonuçlar ışığında, kadın yatırımcıların riske girme sıklığının erkeklere göre çok daha az olduğu görülmektedir. Bu bulgular, literatürdeki diğer çalışmaları destekler nitelikte olup, erkeklerin risk alma eğilimlerinin kadınlara göre daha fazla olduğunu göstermektedir. Riski göze alan yatırımcıların medeni durumları incelendiğinde, genel olarak evli yatırımcıların bekar yatırımcılara oranla daha az riske girme eğiliminde olması, yatırımcıların risk alma düzeylerinde medeni durumun etkin rol oynadığını göstermektedir.

\section{KAYNAKLAR}

Anbar, Adem - Eker, Melek (2009), "Bireysel Yatırımcıların Finansal Risk Algılamalarını Etkileyen Demografik ve Sosyoekonomik Faktörler”, ZKÜ Sosyal Bilimler Dergisi, Cilt: 5, Say1: 9, ss. 129-150.

Aren, Selim - Kaya, Mustafa İdris Yasef - Aydemir, Sibel Dinç (2014), "Davranışsal Finans: Finans Teorisinde Farklı Bir Persfektif", LEGES Bankacılık ve Finans Hukuku Dergisi, Cilt: 1, Sayı: 1, ss. 39-51.

Bostanc1, F. (2003), "Davranış̧̧ Finans”, Sermaye Piyasası Kurulu Yeterlilik Etüdü, No: 57. 
Cameron, Adrian Colin - Trivedi, Pravin K. (2005), Microeconometrics Methods and Applications, Cambridge University Press, Cambridge.

Cameron, Adrian Colin - Trivedi, Pravin K. (2009), Microeconometrics Using Stata, Stata Press Books, College Station, Texas.

Ede, Müjdat (2007), “Davranışsal Finans ve Bireysel Yatırımcı Davranışları Üzerine Ampirik Bir Uygulama”, Marmara Üniversitesi, Bankacılık ve Sigortacılık Enstitüsü Sermaye Piyasası ve Borsa Anabilim Dalı, Yayımlanmamış Yüksek Lisans Tezi, İstanbul.

Elmas, Bekir (2010), "Hisse Senedi Yatırımcılarının Davranışsal Özellikleri-Bireysel Yatırımcıya Yönelik Bir Araştırma”, Atatürk Üniversitesi Sosyal Bilimler Enstitüsü İşletme Anabilim Dalı Muhasebe Finansman Bilim Dalı, Yayımlanmamış Doktora Tezi, Erzurum.

Farrell, James (2011), "Demographics of Risky Investing", Research in Business and Economics Journal - Special Edition, Florida Economic Symposium, May, pp. 1-20.

Fuller, Russell J. (1998), "Behavioral Finance And The Sources Of Alpha”, Journal of Pension Plan Investing, Vol: 2, No: 3, pp. 291-293.

Gümüş, Fatih B. - Koç, Mustafa. - Agalarova Mirsariyya. (2013). "Bireysel Yatırımcıların Yatırım Kararları Üzerinde Etkili Olan Demografik ve Psikolojik Faktörlerin Tespiti Üzerine Bir Çalışma: Türkiye ve Azerbaycan Uygulaması”, KAÜ İ̈BF Dergisi, Cilt: 4, Say1: 6, ss. 71-93.

Jain, Dhiraj - Mandot, Nikhil (2012), “Impect of Demographic Factors on Investment Decision of Investors in Rajasthan”, International Refereed Research Journal Vol: 3, No: 2, pp. 81-92.

Kahyaoğlu, Mehmet Burak (2011), "Yatırım Kararlarına Etki Eden Çeşitli Duygusal ve Psikolojik Faktörlere Maruz Kalma Düzeyi Üzerinde Cinsiyetin Rolü: İMKB Bireysel Hisse Senedi Yatırımcıları Üzerine Bir Uygulama”, Ekonomik ve Sosyal Araştırmalar Dergisi, Cilt: 7, Say1: 1, ss. 29-51.

Karan, Mehmet Baha (2013), Yatırım Analizi ve Portföy Yönetimi, Gazi Yayınları, 4. Bask1, Ankara.

Lutfi, Lutfi (2011). The Relationship Between Demographic Factors And Investment Decision In Surabaya. Journal of Economics, Business, and Accountancy Ventura, Vol: 13, No: 3, pp. 213-224.

Nguyen, Tristan - Schübler, Alexander (2012), "Investment Decisions and SocioDemographic Characteristics Emperical Evidence from Germany", Internatinal Journal of Economics and Finance, Vol: 4, No: 9, pp. 1-12.

Özaltın, Seher - Ersoy, Ersan - Bekci, İsmail (2015), “Kar Dağıtım Politikasının Bireysel Yatırımcıların Yatırım Kararları Üzerine Etkisi”, Süleyman Demirel Üniversitesi İktisadi Ve İdari Bilimler Fakültesi Dergisi, Cilt: 20, Sayı: 2, ss. 397-411. 
Özcan, Handan (2011), "Davranışsal Finansın Bireysel Yatırımcıların Karar Mekanizmaları Üzerindeki Etkileri: Finansal Yatırımcıların Değerlendirilmelerine Yönelik Bir Araştırma", Yayımlanmamış Yüksek Lisans Tezi, Nevşehir Hacı Bektaş Veli Üniversitesi SBE, Nevşehir.

Özerol. Hakan (2011), Davranışsal Finans, Elma Yayınevi, Ankara.

Özerol, Hakan. - Camgöz, Selin Metin. - Karan, Mehmet Baha. - Ergeneli, Azize. (2011), "Determining the Performance of Invidual Investors: the Predictive Roles of Demographic Variables and Trading Strategies", International Journal of Business and Social Science, Vol: 2, No: 18, pp. 86-92.

Rajdev, Ankita (2013), "The Effect of Demographic Factors on Investment Choice of Investors: A Study on Investors of Bhopal", IRC's Internatinal Journal of Multidisciplinary Research in Social \& Management Sciences, Vol: 1, No: 3, pp. 110116.

Sadiq, Muhammad Nauman - Ishaq, Hafiz Muhammad (2014), “The Effect of Demographic Factors on the Behavior of Investors during the Choice of Investments: Evidence from Twin Cities of Pakistan", Global Journal of Management and Business Research: C Finance, Vol: 14, No: 3, pp. 46-56.

Saraç, Mehmet - Kahyaoğlu, Mehmet Burak (2011), "Bireysel Yatırımcıların Risk Alma Eğilimine Etki Eden Sosyo-Ekonomik ve Demografik Faktörlerin Analizi”, BDDK Bankacilık ve Finansal Piyasalar, Cilt: 5, Sayı: 2,ss. 135-157.

Sarıkamış, Cevat (2000), Sermaye Pazarları, Alfa Yayınları, Bursa.

Sefil, Sinem - Çilingiroğlu, Hakkı Kutay (2011), "Davranışsal Finansın Temelleri: Karar Vermenin Bilişsel Ve Duygusal Eğilimleri", İstanbul Ticaret Üniversitesi Sosyal Bilimler Dergisi, Cilt: 10, Say1: 19,ss. 247-268.

Statman, Meir (2014), "Behavioral finance: Finance with normal people", Borsa İstanbul Review, Vol: 14, No: 2, pp. 65-73.

Taner, Berna - Akkaya, G. Cenk (2005), "Yatırımcı Psikolojisi ve Davranışsal Finans Yaklaşımı", Muhasebe ve Finansman Dergisi, Sayı: 27, ss. 47-54.

Usul, Hayrettin - Bekçi, İsmail - Eroğlu, A. Hüsrev (2002), "Bireysel Yatırımcıların Hisse Senedi Edinimine Etki Eden Sosyo-Ekonomik Etkenler”, Erciyes Üniversitesi İktisadi ve İdari Bilimler Fakültesi Dergisi, Sayı: 19, ss. 135-150.

Zaidi, Farheen Btool - Tauni, Muhammad Zubair (2012), "Influence of Investor's Personality Traits and Demographics on Overconfidence Bias", Interdisciplinary Journal of Contemporaray Research in Business, Vol: 4, No: 6, pp. 730-746. 